seriously irresponsible conduct on the part spot inquiry and duly report to the coroner. of the patient and requires or is susceptible - I am, etc., to medical treatment") was clearly applicable in the case of this patient. It followed therefore that as the conduct was caused by brain damage, the Act required the classification to be that of "psychopathic disorder" and not "mental illness," with the consequences which are set out in your correspondent's article.

I seriously doubt whether any mental disorder which is a disability of the mind caused by brain damage can be classified as "mental illness" for the purposes of the Act. This would not prevent a classification of "mental illness" if such a patient suffered from some secondary disorder also (such as.dementia), amounting to mental illness.

The position of a patient who suffers from mental illness which results in "seriously irresponsible conduct," etc., is unclear, having regard to the watertight compartments laid down in section 4. It is difficult to see how a classification of "mental illness" in such a case could be faulted.-I am, etc.,

JAMES A. COOKR Chairman Mental Health Review Tribunal for the South-west Metropolitan Regional Hospital

London W.C.1

1 In re V. E. (Mental Health Patient) The Times, 2 All England Law Reports, 1972, 3, 373.

\section{Deaths Associated with General Dental} Anaesthesia

SIR,-Dr. M. P. Coplans and Mr. I. Curson (13 January, p. 109) report that evidence at a coroner's court is seldom adequate for determining the precise cause of death in these cases; if the investigator is to make a valid diagnosis, they suggest, it has to be supplemented through personal communication with those present in the surgery when the collapse occurred.

With this I entirely agree. Applying this principle I have, over the years, investigated a considerable number of these fatalities and very rarely indeed has the correct explanation emerged from the coroner's court Often the inquest is delayed several weeks, by which time the evidence of those most closely involved in the shattering catastrophe tends to be influenced by hindsight and other considerations. Nor is the expert witness always as informed and impartial as the coroner may suppose. And since nearly all the victims of this sudden unexpected collapse are young and healthy, necropsy is essentially negative. The pathologist will report oedema of the lungs and congestion of the viscera, which are common findings, but to explain the death he has recourse to such suggestions as asphyxia (even though there had been no cyanosis or other sign of suffocation under the anaesthetic, only pallor), idiosyncrasy to one of the agents used (nitrous oxide, trichlorethylene, halothane, and methohexitone have all been blamed), "anaesthetic shock," vagal inhibition associated with thymic hypertrophy, or even (in 1970) "status thymolymphaticus."

Truth and science would be better served were a panel of experts, at least two in number and of the highest academic standing, commissioned the moment a death associated with general dental anaesthesia was notified to hold an immediate on-the-
Salisbury, Wilts

\section{J. G. BOURNE}

Lester would, that difficulty in treating psychological disorder in the young is the explanation. Trends in admission rates for the younger age groups in fact run counter to those for the older part of the population. Between 1964 and 1970 first admission rates for the 15-19 age group increased $^{2}$ while rates for the other age groups decreased. Secular trends in suicide statistics are often easier to observe than explain.-I am, etc.,

B. M. BARractovgh

January, p. 157) mentions the tion of imported hair and wool, which has iscontinued.

The Government Wool Disinfecting Station in Liverpool was opened in 1921 but was closed some two years ago. The reasons given by the Department of Employment for its closure were that considerable quantities of imported hair and wool were coming in through other ports, and that the manufacturers of these raw. materials were now sufficiently equipped to cleanse the consignments of hair and wool as part of the manufacturing process. During its existence the station dealt with many hundreds of consignments of imported hair and wool. These were tested bacteriologically before and after being treated by the Duckering process. Very many of the consignments were heavily infected with anthrax spores on receipt. However, the process was so effective that I cannot recall a positive result after the material was treated.

As these infected consignments of wool and hair are now being widely distributed to various parts of the country I would think it worth while for the Department of Employment to prepare a list of manufacturing processes in which these potentially infected materials are used so that doctors seeing patients working in these processes may be alerted to the anthrax hazard. If it is important, as our tropical disease colleagues exhort us, to ask the patient "Where have you been?", I would suggest that for any patient visiting his doctor with an inflammatory skin lesion it is equally important for the doctor to ask "What materials do you handle at work?"-I am, etc.,

Port Health Authority

ANDREW D. SEMPLE

iverpool

\section{Suicide Rate}

SIR,-The suicide statistics of the past decade are remarkable for the steady decline in the suicide rate, beginning in 1964. That decline is present in all age and sex groups (see table); the young have not been excluded as Dr. D. Lester (9 December, p.

Suicide Rates in England and Wales per 100,000 by Age and Sex, 1963 and $1970^{\circ}$

\begin{tabular}{|c|c|c|c|c|c|c|}
\hline \multirow{3}{*}{$\underset{\text { (years) }}{\text { Age }}$} & \multicolumn{3}{|c|}{ Men } & \multicolumn{3}{|c|}{ Women } \\
\hline & \multicolumn{2}{|c|}{ Rate } & \multirow{2}{*}{ Change } & \multicolumn{2}{|c|}{ Rate } & \multirow{2}{*}{$\begin{array}{c}\% \\
\text { Change }\end{array}$} \\
\hline & 1963 & 1970 & & 1963 & 1970 & \\
\hline $\begin{array}{l}15-24 \\
25-44 \\
45-64 \\
65-74 \\
75+ \\
\text { All ages }\end{array}$ & $\begin{array}{l}6.9 \\
14 \\
26 \\
34 \\
39 \\
14\end{array}$ & $\begin{array}{c}6 \\
10 \\
16 \\
21 \\
24 \\
9.5\end{array}$ & $\begin{array}{l}-13 \\
-29 \\
-38 \\
-38 \\
-38 \\
-32\end{array}$ & $\begin{array}{c}3 \cdot 1 \\
9.6 \\
17 \\
20 \\
18 \\
9 \cdot 9\end{array}$ & $\begin{array}{c}2.6 \\
5.9 \\
12 \\
15 \\
9 \cdot 7 \\
6.6\end{array}$ & $\begin{array}{l}-16 \\
-39 \\
-29 \\
-25 \\
-46 \\
-33\end{array}$ \\
\hline
\end{tabular}

612) states, provided we look at the most recent statistics. ${ }^{1}$ It is true that the suicide rate for the 15-24 age group has not gone down as much as the older age groups suicide rates, but it would be hasty to infer,

\section{M.R.C. Clinical Psychiatry Unit,}

Chichester, Sussex Registrar General, Statistical Reviews for England
and Wales, 1963 and 1970, London, H.M.S.O., 1965, 1972.

Department of Health and Social Security, Psychiatric Hospitals and Units in England and No. 4, 1970. London, H.M.S.O., 1972.

\section{Radiological Pseudotumour in Chronic} Ulcerative Colitis

SIR,-In two cases of ulcerative colitis radiological evidence indicating stricture due to tumour formation was obtained. In neither case was a tumour or stricture found to be present at operation; nevertheless, histological examination at these sites showed cancer to be present.

Case 1.-A woman aged 34 known to have had ulcerative colitis for 11 years was having six to eight bowel actions $a$ day at the time of her admission to hospital. The stools were fluid, containing blood, pus, and mucus. She had colicky pain in the right iliac fossa. On examination no abdominal tumour could be felt. $A$ barium enema showed extensive ulcerative colitis of long standing with a constant stenotic lesion at the hepatic flexure (fig. 1). This lesion

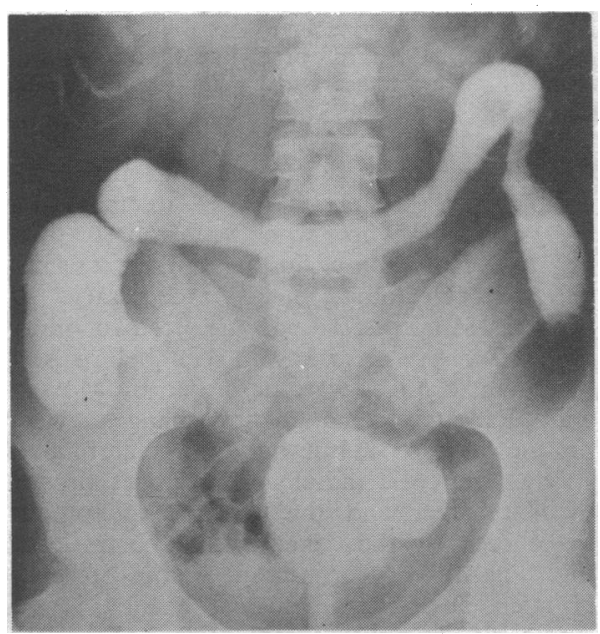

FTo. 1.-Barium enema showing changes of chronic ulcerntive colitis with constant stricture at the hepatic flexure. Case 1.

was still present at a second barium enema undertaken a month later. Panproctocolectomy was therefore performed. At operation neither stenosis nor tumour could be found, though the whole colon was markedly thickened, with increased vascularity. Examination of the colon after removal revealed no evidence of cancer either as a stricture or a tumour. Histological examination showed a moderately welldifferentiated adenocarcinoma to be present at the site of the radiological tumour. No penetration of the bowel wall had occurred and no lymph nodes were involved. She remains well after 17 years' follow-up.

Case 2.-A 28-year-old man developed septic
Graylingwell Hospital, 